\title{
Pembelajaran Berbasis Masalah Berbantuan Kartu Jawaban Bersambung untuk Meningkatkan Hasil Belajar Fisika di SMA Negeri 10 Mataram
}

\author{
I Made Narta Widianta \\ SMA Negeri 9 Mataram, Kota Mataram - Provinsi NTB \\ Corresponding Author. Email: paknarta2020@gmail.com
}

\begin{abstract}
This study aims to improve physics learning outcomes in the knowledge aspect through the application of Problem Based Learning assisted with Continuous Answer Cards. This research method used classroom action research. The subjects of this study were students of class X MIPA 2 SMAN 10 Mataram consisting of 26 people. The technique of collecting data on the results of learning physics uses a written test which is carried out through daily tests. The data analysis technique of this research was carried out descriptively. The results showed that there was an increase in the students' physics learning outcomes compared to their pre-cycle scores by $27 \%$ in the first cycle, $56 \%$ in the second cycle and $80 \%$ in the third cycle. The average value of students' physics learning outcomes increased, namely 51 in the pre-cycle, 54 in the first cycle, 66 in the second cycle, and 72 in the third cycle. The percentage of classical learning completeness with a KKM score of 70 also increased, namely $30 \%$ in the pre-cycle to $38 \%$ in the first cycle then to $58 \%$ in the second cycle and to $70 \%$ in the third cycle. Thus it can be concluded that Problem Based Learning assisted by Continuous Answer Cards can improve learning outcomes of physics in the aspects of knowledge of class X MIPA 2 students of SMAN 10 Mataram.
\end{abstract}

Abstrak: Penelitian ini bertujuan untuk meningkatkan hasil belajar fisika pada aspek pengetahuan melalui penerapan Pembelajaran Berbasis Masalah berbantuan Kartu Jawaban Bersambung. Metode penelitian ini menggunakan penelitian tindakan kelas. Subjek penelitian ini adalah peserta didik kelas $\mathrm{X}$ MIPA 2 SMAN 10 Mataram yang terdiri atas 26 orang. Teknik pengumpulan data hasil belajar fisika menggunakan tes tertulis yang dilaksanakan melalui ulangan harian. Teknik analisis data penelitian ini dilakukan secara deskriptif. Hasil penelitian menunjukkan bahwa terjadi peningkatan nilai hasil belajar fisika siswa dibandingkan nilainya pada prasiklus sebesar $27 \%$ pada siklus pertama, $56 \%$ pada siklus kedua dan $80 \%$ pada siklus ketiga. Nilai rata-rata hasil belajar fisika peserta didik semakin meningkat yaitu 51 pada prasiklus, 54 pada siklus pertama, 66 pada siklus kedua, dan 72 pada siklus ketiga. Persentase ketuntasan belajar klasikal dengan nilai KKM 70, juga semakin meningkat yaitu $30 \%$ pada prasiklus menjadi $38 \%$ pada siklus pertama kemudian menjadi $58 \%$ pada siklus kedua dan menjadi $70 \%$ pada siklus ketiga. Dengan demikian dapat disimpulkan bahwa Pembelajaran Berbasis Masalah berbantuan Kartu Jawaban Bersambung dapat meningkatkan hasil belajar fisika pada aspek pengetahuan siswa kelas X MIPA 2 SMAN 10 Mataram.
Article History

Received: 26-02-2021

Revised: 29-03-2021

Published: 14-04-2021

Key Words:

Problem Based Learning, Continuous Answer Cards, Learning

Outcome.

\section{Sejarah Artikel}

Diterima: 26-02-2021

Direvisi: 29-03-2021

Diterbitkan: 14-04-2021

\section{Kata Kunci: \\ Pembelajaran Berbasis Masalah, Kartu Jawaban Bersambung, Hasil Belajar.}

How to Cite: Widianta, I. (2021). Pembelajaran Berbasis Masalah Berbantuan Kartu Jawaban Bersambung untuk Meningkatkan Hasil Belajar Fisika di SMA Negeri 10 Mataram. Jurnal Teknologi Pendidikan : Jurnal Penelitian dan Pengembangan Pembelajaran, 6(1). doi:https://doi.org/10.33394/jtp.v6i1.3598 


\section{Pendahuluan}

Sains atau Fisika merupakan cara mencari tahu tentang alam secara sistematis untuk menguasai pengetahuan, fakta, konsep, prinsip, proses penemuan dan memiliki sikap ilmiah (Soekarman, 2021). Konsep-konsep fisika yang membutuhkan pemikiran tingkat tinggi sering memunculkan kesulitan bagi peserta didik untuk memahaminya. Karena itu diperlukan kehadiran guru untuk membantu peserta didik dalam memfasilitasi segala hal yang diperlukan oleh peserta didik seperti lembar kerja dan model pembelajaran yang cocok untuk mereka. Salah satu teori belajar yang membahas mengenai kesulitan peserta didik serta metode pemberian bantuan kepada peserta didik adalah teori belajar Vygotsky yang diimplementasikan dalam bentuk penerapan suatu lembar kerja dan model pembelajaran yang dapat membantu peserta didik mengasah kemampuannya dalam berpikir tingkat tinggi adalah model pembelajaran berbasis masalah.

Menurut Tan (2003) dalam Rusman (2017), pendekatan Pembelajaran Berbasis Masalah merupakan inovasi dalam pembelajaran karena dalam Pembelajaran Berbasis Masalah kemampuan berpikir siswa betul-betul dioptimalisasikan melalui proses kerja kelompok atau tim yang sistematis sehingga siswa dapat memberdayakan, mengasah, menguji dan mengembangkan kemampuan berpikirnya secara berkesinambungan. Arends (2004) dalam Ngalimun dkk (2014) menyatakan bahwa ada tiga hasil belajar (outcomes) yang diperoleh pebelajar yang diajar dengan Problem Base Learning yaitu: 1) inkuiri dan keterampilan melakukan pemecahan masalah; 2) belajar model peraturan orang dewasa (adult role bahaviors) dan 3) keterampilan belajar mandiri (skills for independent learning). Siswa yang melakukan inkuiri dalam pembelajaran akan menggunakan keterampilan berpikir tingkat tinggi (high order thinking skills) dimana mereka akan melakukan operasi mental seperti induksi, deduksi, klasifikasi dan reasoning. Problem Base Learning juga bertujuan untuk membantu siswa belajar secara mandiri. Muhammad Fathurohman (2015) mengemukan bahwa tahapan-tahapan atau sintaks pembelajaran berbasis masalah sebagai berikut: 1) Tahap 1, mengorientasikan peserta didik terhadap masalah. Guru menjelaskan tujuan pembelajaran dan sarana atau logistik yang dibutuhkan. Guru memotivasi peserta didik untuk terlibat dalam aktivitas pemecahan masalah nyata yang dipilih atau ditentukan; 2) Tahap 2, mengorganisasikan peserta didik untuk belajar. Guru membantu peserta didik mendefinisikan dan mengorganisasi tugas belajar yang berhubungan dengan masalah yang sudah diorientasikan pada tahap sebelumnya; 3) Tahap 3, membimbing penyelidikan individual maupun kelompok. Guru mendorong peserta didik untuk mengumpulkan informasi yang sesuai dan melaksanakan eksperimen untuk mendapatkan kejelasan yang diperlukan untuk menyelesaikan masalah; 4) Tahap 4, mengembangkan dan menyajikan hasil karya. Guru membantu peserta didik untuk berbagi tugas dan merencanakan atau menyiapkan karya yang sesuai sebagai hasil pemecahan masalah dalam bentuk laporan, video atau model; 5). Tahap 5, menganalisis dan mengevaluasi proses pemecahan masalah. Guru membantu peserta didik untuk melakukan refleksi atau evaluasi terhadap proses pemecahan masalah yang dilakukan.

Vygotsky mengatakan bahwa, pembelajaran terjadi apabila anak bekerja atau belajar menangani tugas-tugas yang belum dipelajari namun tugas-tugas itu masih berada dalam jangkauan kemampuannya atau tugas-tugas tersebut berada dalam Zone Proximal Development (Ahmad Susanto,2016 ; Muhammad Fathurrohman, 2017). Selanjutnya Ahmad Susanto (2016) mengungkapkan bahwa ada dua implikasi utama teori Vigotsky dalam pembelajaran sains, pertama, dikehendakinya suasana kelas, berbentuk pembelajaran kooperatif antar siswa, sehingga siswa dapat berinteraksi di sekitar tugas-tugas yang sulit dan 
saling memunculkan strategi pemecahan masalah yang efektif di dalam masing-masing zone of proximal development mereka. Kedua, dalam pembelajaran menekankan scaffolding sehingga siswa semakin lama semakin bertanggung jawab terhadap pembelajarannya sendiri. Muhammad Fathurrohman (2017) mengemukakan bahwa scaffolding adalah memberikan kepada seseorang anak sejumlah besar bantuan selama tahap-tahap awal pembelajaran dan kemudian mengurangi bantuan tersebut dan memberikan kesempatan kepada anak tersebut mengambil alih tanggung jawab yang semakin besar segera setelah ia mampu mengerjakan sendiri. Bantuan yang diberikan guru dapat berupa petunjuk, peringatan, dorongan menguraikan masalah ke dalam bentuk lain yang memungkinkan siswa dapat mandiri. Berkaitan dengan pembelajaran, Vygotsky mengemukakan empat prinsip seperti yang dikutip oleh Slavin (Muhammad Fathurrohman, 2017) yaitu: 1) Pembelajaran sosial (social learning), Vygotsky menyatakan bahwa siswa belajar melalui interaksi bersama dengan orang dewasa atau teman yang lebih cakap; 2) ZPD (zone of proximal development), bahwa siswa akan dapat mempelajari konsep-konsep dengan baik jika berada dalam ZPD. Siswa bekerja dalam ZPD jika siswa tidak dapat memecahkan masalah sendiri, tetapi dapat memecahkan masalah itu setelah mendapat bantuan orang dewasa atau temannya (peer). Bantuan tersebut dimaksudkan agar si anak mampu untuk mengerjakan tugas-tugas atau soalsoal yang lebih tinggi tingkat kerumitannya dari pada tingkat perkembangan si anak; 3) Masa magang kognitif (cognitif apprenticeship), suatu proses yang menjadikan siswa sedikit demi sedikit memperoleh kecakapan intelektual melalui interaksi dengan orang yang lebih ahli, orang dewasa, atau teman yang lebih pandai; 4) Pembelajaran termediasi (mediated learning), Vygotsky menekankan pada scaffolding, siswa diberi masalah kompleks, sulit dan realistik, kemudian diberi bantuan secukupnya dalam memcahkan masalah siswa.

Untuk itu dalam rangka membantu peserta didik agar lebih memudahkan dalam proses memahami konsep-konsep fisika yang sedang diperlajarinya, dibuatlah lembar kerja yang disebut Kartu Jawaban Bersambung yang diterapkan dalam kegiatan Pembelajaran Berbasis Masalah. Adapun tujuan penelitian ini adalah untuk menganalisis pengaruh model pembelajaran berbasis masalah berbantuan kartu jawaban bersambung dalam meningkatkan hasil belajar fisika dalam aspek pengetahuan siswa kelas X MIPA 2 SMAN 10 Mataram.

\section{Metode Penelitian}

Metode penelitian ini menggunakan penelitian tindakan kelas Dalam penelitian ini variabel yang diteliti adalah peningkatan hasil belajar Fisika pada aspek pengetahuan siswa setelah mendapat tindakan berupa penerapan pembelajaran berbasis masalah berbantuan kartu jawaban bersambung. Subyek penelitian ini adalah peserta didik kelas X MIPA 2 SMAN 10 Mataram yang berjumlah 26 orang.

Hasil belajar peserta didik merupakan data-data yang diperoleh dari hasil ulangan harian dengan instrumen berupa soal dalam bentuk tes tertulis yang dibuat oleh guru. Datadata kuantitatif tersebut dianalisis secara deskriptif dengan cara disusun dalam bentuk tabel kemudian dilakukan perhitungan untuk mengetahui nilai rata-rata kelas dan persentase ketuntasan belajar peserta didik secara klasikal dengan patokan nilai kriteria ketuntasan minimum (KKM) sebesar 70. Untuk mengetahui terjadinya peningkatan hasil belajar maka dilakukan perhitungan persentase peningkatan nilai tiap peserta didik di setiap siklus pembelajaran dibandingkan dengan nilainya pada prasiklus. Bila $70 \%$ atau lebih peserta didik berhasil mencapai nilai kriteria ketuntasan minimal (KKM) sebesar 70 dan nilai rata-rata kelas sama dengan atau lebih besar dari 70 maka pembelajaran ini dikatakan berhasil.

Materi pokok yang dipelajari peserta didik sebelum pemberian tindakan adalah 
Pengukuran, sedangkan materi pokok yang dipelajari peserta didik saat diterapkannya Pembelajaran Berbasis Masalah (PBM) berbantuan Kartu Jawaban Bersambung ini adalah Vektor Poligon pada siklus I, Vektor Analisis pada siklus II dan Gerak Lurus pada siklus III.

\section{Hasil Penelitian dan Pembahasan}

Berdasarkan hasil analisis data seperti diperlihatkan pada Tabel 1, maka telah terjadi peningkatan nilai hasil belajar fisika peserta didik setelah diberi tindakan dibandingkan nilai hasil belajar fisika peserta didik pada prasiklus. Pada siklus pertama terjadi peningkatan nilai sebesar $27 \%$, pada siklus kedua terjadi peningkatan nilai sebesar $56 \%$ dan pada siklus ketiga terjadi peningkatan nilai sebesar $80 \%$. Berdasarkan hasil analisis data seperti diperlihatkan pada Tabel 2, ternyata nilai rata-rata hasil belajar fisika peserta didik semakin meningkat. Pada prasiklus nilai rata-rata yang diperoleh peserta didik sebesar 50, pada siklus pertama meningkat menjadi 54, pada siklus kedua meningkat menjadi 66 dan pada siklus ketiga meningkat menjadi 72. Berdasarkan hasil analisis data pada Tabel 3, ternyata persentase ketuntasan belajar peserta didik secara klasikal dengan patokan nilai kriteria ketuntasan minimal (KKM) sebesar 70 juga semakin meningkat. Ketuntasan belajar secara klasikal pada prasiklus sebesar $30 \%$, meningkat menjadi $38 \%$ pada siklus pertama, meningkat lagi pada siklus kedua menjadi 58\% dan pada siklus ketiga menjadi $70 \%$.

Tabel 1. Perbandingan Persentase Peningkatan Nilai Hasil Belajar Fisika Peserta Didik dibandingkan dengan Nilai Hasil Belajar Fisika pada Prasiklus

\begin{tabular}{ccc}
\hline No. & Siklus & Persentase Peningkatan Nilai \\
\hline 1 & Pertama & $27 \%$ \\
2 & Kedua & $56 \%$ \\
3 & Ketiga & $80 \%$ \\
\hline
\end{tabular}

Tabel 2. Perbandingan Nilai Rata-rata Hasil Belajar Fisika Peserta Didik pada Prasiklus, Siklus I, Siklus II dan Siklus II

\begin{tabular}{ccc}
\hline No. & Siklus & Persentase Peningkatan Nilai \\
\hline 1 & Pra & 50 \\
2 & Pertama & 54 \\
3 & Kedua & 66 \\
4 & Ketiga & 72 \\
\hline
\end{tabular}

Tabel 3. Perbandingan Persentase Ketuntasan Belajar Peserta Didik Secara Klasikal dengan Nilai Kriteria Ketuntasan Minimal 70.

\begin{tabular}{ccc}
\hline No & Siklus & Persentase Peningkatan Nilai \\
\hline 1 & Pra & $30 \%$ \\
2 & Pertama & $38 \%$ \\
3 & Kedua & $58 \%$ \\
4 & Ketiga & $70 \%$ \\
\hline
\end{tabular}

Sebelum pemberian tindakan atau pada pembelajaran prasiklus, penerapan model pembelajaran berbasis masalah dengan buku paket sebagai sumber belajarnya, tidak bisa berjalan dengan lancar. Di kegiatan awal, peserta didik relatif siap untuk mengikuti kegiatan pembelajaran. Namun pada kegiatan inti, setelah guru memberikan orientasi masalah terkait dengan materi pelajaran kemudian memberikan tugas kepada peserta didik untuk mengumpulkan informasi dari buku paket dengan melakukan literasi, maka sebagian peserta didik tidak bersemangat untuk menyelesaikan tugas itu, mereka melakukan hal-hal lain. Sebagian besar peserta didik lebih banyak berdiam diri ketika mengalami kesulitan dalam menyelesaikan masalah terutama soal-soal yang membutuhkan pemikiran tingkat tinggi, 
sehingga penyelesaian soal berlangsung dalam waktu relatif lama. Peserta didik cenderung bekerja sendiri-sendiri dan pada kegiatan akhir pembelajaran, kegiatan pembuatan kesimpulan hasil pembelajaran cenderung dilakukan oleh guru. Tapi selama pemberian tindakan, kualitas proses pembelajaran menjadi semakin meningkat. Dibandingkan kegiatan pembelajaran sebelum pemberian tindakan, pada saat pemberian tindakan peserta didik relatif lebih siap untuk mengikuti kegiatan pembelajaran. Tahap-tahap pelaksanaan pembelajaran berbasis masalah dapat terlaksana dengan baik, walaupun pada siklus pertama masih menemui beberapa kendala. Kegiatan pembelajaran pada siklus pertama belum berjalan dengan sempurna karena beberapa peserta didik belum bisa melaksanakan kegiatan pembelajaran seperti yang diharapkan. Karena itu pada awal kegiatan pembelajaran siklus kedua, guru menjelaskan prosedur pelaksanaan pembelajaran secara lebih terperinci. Peserta didik yang terdeteksi kurang bersemangat pada pembelajaran siklus pertama diberikan pemahaman dan di motivasi untuk ikut berperan aktif mendukung kegiatan pembelajaran bersama teman-temannya di kelas. Kegiatan pembelajaran pada siklus kedua bisa berjalan lebih lancar dan pada siklus ketiga menjadi semakin lancar sesuai harapan. Sebagian besar peserta didik melakukan kegiatan pembelajaran melalui kerja kelompok dengan panduan lembar kerja berupa Kartu Jawaban Bersambung, beberapa peserta didik mau bertanya pada teman maupun guru, beberapa peserta didik yang telah berhasil mengerjakan soal relatif lebih berani dan lebih bersemangat untuk mempresentasikan hasil pekerjaannya di depan kelas, diskusi kelas berlangsung dengan baik, penyelesaian masalah berlangsung relatif lebih cepat, sebagian besar peserta didik melakukan kegiatan permainan (mengurutkan Kartu Jawaban Bersambung) dengan penuh semangat, dan kegiatan pembuatan kesimpulan hasil pembelajaran berlangsung dengan baik berdasarkan hasil diskusi kelas dengan melibatkan peserta didik dan guru.

Hasil belajar peserta didik yang cenderung menjadi semakin baik ini tidak bisa terlepas dari pengaruh tindakan yang telah diberikan yaitu dengan penerapan lembar kerja berupa Kartu Jawaban Bersambung dalam Pembelajaran Berbasis Masalah. Kartu Jawaban Bersambung merupakan suatu media untuk memfasilitasi peserta didik dalam memecahkan masalah-masalah yang terkait dengan konsep-konsep fisika yang membutuhkan pemikiran tingkat tinggi. Kartu Jawaban Bersambung adalah lembar kerja yang berisi masalah dan potongan-potongan jawaban yang disusun secara acak dimana jawaban masalah itu akan diketahui oleh peserta didik setelah mereka menyusun potongan-potongan jawaban itu dengan benar. Kartu Jawaban Bersambung ini dapat memberi bantuan kepada peserta didik yang merasa kebingungan dan kehabisan ide untuk menyelesaikan masalah, karena langkahlangkah penyelesaian masalahnya telah dibagi-bagi menjadi beberapa bagian kecil yang detail. Dengan pembagian seperti itu maka peserta didik akan lebih mudah memahami materi pelajaran yang terkandung dalam bagian-bagian kecil itu. Kartu Jawaban Bersambung ini dibuat oleh guru. Penerapan Kartu Jawaban Bersambung ini dikondisikan dalam suasana bermain yaitu permainan menyusun potongan-potongan jawaban yang dilakukan dalam kerja kelompok. Dengan demikian, peserta didik akan mendapat bantuan dari teman-temannya dan guru dalam suasana pembelajaran yang lebih menyenangkan.

Sesuai tahapan pada Pembelajaran Berbasis Masalah, maka masalah yang disajikan dalam Kartu Jawaban Bersambung itu merupakan stimulus bagi peserta didik pada tahap 1 pembelajaran yaitu mengorientasikan peserta didik terhadap masalah. Dengan menerapkan lembar kerja ini dalam kegiatan pembelajaran maka guru dapat menjelaskan tujuan pembelajaran dan sarana yang dibutuhkan, sekaligus guru memotivasi peserta didik untuk terlibat dalam aktivitas pemecahan masalah nyata yang dipilih atau ditentukan tersebut. 
Disamping itu tahap 2 pembelajaran berbasis masalah yaitu mengorganisasikan peserta didik untuk belajar juga dapat terkondisikan dengan mudah, dalam hal ini guru membantu peserta didik mendefinisikan dan mengorganisasi tugas belajar yang berhubungan dengan masalah yang sudah diorientasikan pada tahap sebelumnya. Tahap 3 dalam kegiatan pembelajaran ini yaitu membimbing penyelidikan individual maupun kelompok juga dapat dikendalikan, dalam hal ini guru mendorong peserta didik untuk mengumpulkan informasi yang sesuai dengan cara membaca buku paket atau bahan ajar yang disediakan guru. Selanjutnya berdasarkan hasil kerja pada tahap 3, maka pembelajaran pada tahap 4, yaitu mengembangkan dan menyajikan hasil karya juga dapat dilaksanakan dengan baik, dalam hal ini guru membantu peserta didik untuk mempresentasikan hasil pekerjaannya. Demikian pula pembelajaran pada tahap 5 yaitu menganalisis dan mengevaluasi proses pemecahan masalah juga dapat dilakukan, dalam hal ini guru membantu peserta didik untuk melakukan refleksi atau evaluasi terhadap proses pemecahan masalah yang dilakukan.

Salah satu cara untuk membantu peserta didik yang sedang mengalami kesulitan belajar adalah dengan penerapan Pembelajaran Berbasis Masalah berbantuan Kartu Jawaban Bersambung. Dengan penerapan Pembelajaran Berbasis Masalah, maka peserta didik dilatih untuk memecahkan masalah-masalah yang relatif sulit. Sedangkan dengan Kartu Jawaban Bersambung, peserta didik dibantu untuk melaksanakan kegiatan belajar secara berkelompok melalui suatu kegiatan bermain. Dengan pemberian tindakan seperti ini dalam kegiatan pembelajaran maka peserta didik selalu dihadapkan pada suatu tantangan yang harus diselesaikannya. Dalam menyelesaikan tantangan itu, peserta didik selalu dikondisikan untuk saling membantu melalui kegiatan permainan yang harus dilakukannya dalam kelompok. Disamping itu peserta didik juga dilatih untuk bertanggung jawab terhadap hasil kerja kelompoknya yaitu dengan mempresentasikannya pada suatu diskusi kelas yang dibimbing oleh guru.

Melalui tindakan yang diberikan pada penelitian tindakan kelas ini, maka guru mempunyai banyak kesempatan untuk melaksanakan segala fungsinya sebagai fasilitator dalam kegiatan pembelajaran, seperti pada saat peserta didik (dalam salah satu kelompok) mengalami kesulitan belajar, maka guru punya kesempatan membantu peserta didik secara lebih mendalam secara individual. Begitu pula pada saat peserta didik sedang melakukan diskusi kelompok, maka guru punya kesempatan untuk berkeliling kelas sehingga bisa memastikan seluruh peserta didik melakukan kegiatan belajarnya dengan baik.

\section{Kesimpulan}

Berdasarkan hasil penelitian ini maka dapat disimpulkan bahwa Pembelajaran Berbasis Masalah berbantuan Kartu Jawaban Bersambung dapat meningkatkan hasil belajar fisika pada aspek pengetahuan peserta didik kelas X MIPA 2 SMAN 10 Mataram. Hasil penelitian menunjukkan bahwa peningkatan nilai hasil belajar fisika siswa dibandingkan nilainya pada prasiklus sebesar $27 \%$ pada siklus pertama, $56 \%$ pada siklus kedua dan $80 \%$ pada siklus ketiga. Nilai rata-rata hasil belajar fisika peserta didik semakin meningkat yaitu 51 pada prasiklus, 54 pada siklus pertama, 66 pada siklus kedua, dan 72 pada siklus ketiga. Persentase ketuntasan belajar klasikal dengan nilai KKM 70, juga semakin meningkat yaitu $30 \%$ pada prasiklus menjadi $38 \%$ pada siklus pertama kemudian menjadi 58\% pada siklus kedua dan menjadi $70 \%$ pada siklus ketiga. 


\section{Saran}

Berdasarkan temuan yang diperoleh dari penelitan ini maka saran yang bisa disampaikan antara lain: 1) untuk pengembangan penelitian lebih lanjut perlu diadakan penelitian serupa di sekolah lain pada mata pelajaran lain yang serumpun; 2) untuk guru fisika yang ingin menerapkan pendekatan pembelajaran ini, perlu memotivasi seluruh peserta didik agar mengikuti semua tahapan pembelajaran, karena biasanya setelah menyelesaikan tugas kelompoknya maka sebagian peserta didik merasa tidak perlu untuk mencatat hasil yang diperoleh oleh kelompok lain yang sedang membahas masalah berbeda; 3) sekolah perlu mendukung segala kegiatan penelitian tindakan kelas yang dilakukan guru dalam upaya membantu kesulitan peserta didik sehingga hasil belajarnya meningkat.

\section{Daftar Pustaka}

A.Wahab Jufri. (2013). Belajar dan Pembelajaran.Pustaka Reka Cipta:Bandung

Ahmad Susanto. (2016). Teori Belajar dan Pembelajaran di Sekolah Dasar. Prenadamedia Group: Jakarta

Aqib, Zainal. (2017). Model-model, Media dan Strategi Pembelajaran Kontekstual (Inovatif). Bandung: Yrama Widya

Azhar Arsyad. (2014). Media Pembelajaran.Jakarta: PT.RajaGrafindo Persada

Baharuddin dan Esa Nur Wahyuni. (2007). Teori Belajar dan Pembelajaran. Ar-ruzz Media: Jogjakarta

Dina Gasong. (2018). Belajar dan Pembelajaran. Deepublish: Yogyakarta

Firmina Angela Nai. (2017). Teori Belajar dan Pembelajaran Implementasinya dalam Pembelajaran di SMP, SMA dan SMK. Deepublish: Yogyakarta

Husamah dkk. (2018). Belajar dan Pembelajaran.Universitas Muhammadiyah Malang: Malang

Lefudin. (2017). Belajar dan Pembelajaran. Deepublish: Yogyakarta

Muhammad Fathurrohman. (2015). Model-model Pembelajaran Inovatif. Ar-ruzz Media: Jogjakarta

Muhammad Fathurrohman. (2017). Belajar dan Pembelajaran Modern. Garudhawaca: Yogyakarta

Ngalimun dkk. (2014). Strategi dan Model Pembelajaran. Scripta Cendikia: Banjar Baru Kalimantan Selatan

Rusman. (2017). Belajar dan Pembelajaran Berorientasi Standar Proses Pendidikan. Kencana: Jakarta

Sardiman, AM. (2012). Interaksi dan Motivasi Belajar Mengajar.Jakarta: PT.RajaGrafindo Persada

Slameto. (2013). Belajar dan Faktor-faktor yang Mempengaruhi.Jakarta: Rineka Cipta.

Soekarman, S. (2021). Impementasi Pembelajaran Fisika Pokok Bahasan Elastisitas Melalui Inquiry Based Learning di SMA Negeri 2 Donggo. Jurnal Paedagogy, 8(2), 197-209. doi:https://doi.org/10.33394/jp.v8i2.3521

Trianto. (2011). Model-model Pembelajaran Inovatif Berorientasi Konstruktivistik. Prestasi Pustaka: Jakarta

Warsona dan Hariyanto. (2012). Pembelajaran Aktif. Remaja Rosdakarya: Bandung Wena, Made. (2019). Strategi Pembelajaran Inovatif Kontemporer. Jakarta: Bumi Aksara Yatim Riyanto. (2014). Paradigma Baru Pembelajaran. Prenadamedia Group: Jakarta 